\title{
Una metodología educativa para estudiar la cultura como eje estructural del desarrollo del emprendimiento
}

\author{
An educational methodology for studying culture as an organizing center in \\ entrepreneurship development
}

\author{
Elena V. Romanenko ${ }^{1 a}$, Elena V. Yaluner ${ }^{2}$, Anastasia S. Strinkovskaya ${ }^{3}$, \\ Michael M. Loubochkin ${ }^{4}$, Anna Al. Kurochkina ${ }^{5}$ \\ The Siberian State Automobile and Highway University, Omsk, Russia ${ }^{1,3}$ \\ St. Petersburg State Economic University, Saint Petersburg, Russia ${ }^{2}$ \\ Saint-Petersburg State University, Saint-Petersburg, Russia ${ }^{4}$ \\ Russian state hydrometeorological University, Saint-Petersburg, Russia ${ }^{5}$
}

iD ORCID ID: https://orcid.org/0000-0002-1448-22881

D ORCID ID: https://orcid.org/0000-0002-1848-3819²

ORCID ID: https://orcid.org/0000-0002-4253-6669 3

iD ORCID ID: https://orcid.org/0000-0002-7482-3099 4

iD ORCID ID: https://orcid.org/0000-0002-7973-59875

Recibido: 03 de julio de 2020

Aceptado: 07 de octubre de 2020

\begin{abstract}
Resumen
Esta investigación tiene como objetivo elaborar un enfoque sistémico y holístico del desarrollo del espíritu empresarial, en relación con la compleja interacción de factores culturales y económicos. Los objetivos de la investigación incluyen proponer un nuevo paradigma económico y cultural para estudiar el espíritu empresarial y fundamentar la disposición sobre la naturaleza endógena de la relación entre cultura y empresa. La hipótesis de investigación implica el supuesto de que la cultura económica debe considerarse como un marco de apoyo de una sola realidad económica, y la cultura empresarial debe considerarse como la estructura principal de los modelos de comportamiento empresarial. Los métodos de investigación se basan en el análisis y la comparación de las teorías convencionales y alternativas, en cuyo marco se formaron las ideas sobre la actividad empresarial. Se propuso una metodología alternativa que surgió bajo la influencia del giro cognitivo-cultural en las ciencias sociales basada en la complementariedad de los enfoques estructural-funcional y comunicativo-semántico. El significado conceptual de esta metodología es aclarar el papel de la cultura como factor vertebrador en el desarrollo de la actividad emprendedora. La relevancia del estudio está determinada por el cambio en la naturaleza y los mecanismos de las actividades empresariales,
\end{abstract}


el creciente papel de la cultura en la economía y la falta de enfoques teóricos y metodológicos satisfactorios.

Palabras clave: metodología, cultura, emprendimiento, paradigma, mainstream.

\begin{abstract}
This research is aimed at working out a systemic and holistic approach to entrepreneurship development, regarding the complex interaction of cultural and economic factors. The research objectives include proposing a new economic and cultural paradigm to study entrepreneurship and to substantiate the provision on the endogenous nature of the relationship between culture and business. The research hypothesis implies the assumption that economic culture should be considered as a supporting frame of a single economic reality, and entrepreneurial culture should be regarded as a backbone structure of entrepreneurial behavior models. The research methods are based on the analysis and comparison of the mainstream and alternative theories, within the framework of which ideas about entrepreneurial activity were formed. An alternative methodology was proposed that arose under the influence of the cognitive-cultural turn in the social sciences based on the complementarity of the structural-functional and communicativesemantic approaches. The conceptual meaning of this methodology is to clarify the role of culture as a backbone factor in the development of the entrepreneurial activity. The relevance of the study is determined by the change in the nature and mechanisms of entrepreneurial activities, the growing role of culture in the economy, and the lack of satisfactory theoretical and methodological approaches.
\end{abstract}

Keywords: methodology, culture, entrepreneurship, paradigm, mainstream.

\title{
Introduction
}

Current qualitative changes in the development of national economies are caused by profound changes in the conditions of economic activities, their nature, and implementation mechanisms. They are accompanied by the emergence of a new system of interrelated factors, driven by the growing importance of knowledge and innovation to increase productivity and create sustainable competitive advantages (Alesina \& Giuliano, 2016; Atkin, 2016; Barsbai, Rapoport, Steinmayr, \& Trebesch, 2017). Nowadays, an ever-increasing number of representatives of heterodox economics are inclined to believe that the problem of the proper inclusion of culture in the economy is determined primarily by the development of a scientific worldview of economic reality and the appropriate system of principles employed by the economics to study its aspect of the integral world of social reality. According to Phillip O'Hara (2009), the analysis of the role of culture in the socio-economic process is the starting point of circular and cumulative causality. It is necessary to realize the importance of ideology, values, various norms, and customs. We will be able to give precise wording to stylized facts at the level of technology if we understand the causal links between the assessment of reality by economic agents and the relationship between them. 
The evolution of economics over the past century was accompanied by its division into two coexisting and weakly interacting parts - the dominant and alternative theories, in which ideas about entrepreneurship were formed (Biryukov, 2016; Akhmetshin \& Gayazova, 2017). At the same time, it acquired a complex structure as a result of differentiation of the subject area and fragmentation of knowledge, covering various aspects of economic life and differing in methodological status and research methods, the degree of reliability, and practical significance. Concurrently, none of the competing research programs has been able to offer a holistic and fairly complete picture of the economy, taking into account the complex interaction of cultural and institutional factors (Biryukov and Romanenko, 2017a). Many researchers consider the current state of the economy as a crisis caused by the need to revise the research paradigm that has become established in the mainstream. They see a way out of the crisis of conventional teachings in the creation of a new theory that can combine economic and cultural value-based components since axiological problems affect the essence of economic constructions (Alesina, 2016; Frolov, 2016; Biryukov, 2016).

In these conditions, it is very important to develop a systematic and holistic approach to entrepreneurship development, taking into account the complex interaction of cultural and economic factors and the endogenous nature of the relationship between culture and entrepreneurship.

\section{Literature review}

Currently, the significance of culture is generally recognized. Many contemporary studies empirically show that the peculiarities of culture significantly affect the results of economic activities, the development of the national economy, and economic exchange (Guiso et al., 2006; Guiso et al., 2009; Fernandez, 2008; Fernandez, 2010); innovation and knowledge management at the national and organizational levels (Couto and Vieira, 2004; King, 2007; Ang and Massingham, 2007; Kaywozth and Leidner, 2004); and economic performance of individuals and firms (Algan and Cahuc, 2014).

Subsequent to the dominance of ideas that arose under the influence of distancing from the cultural measurement of the economy in current economics, various concepts have spread which are based on the interpretation of the exogenous relationship between the cultural and economic spheres of human activities (Biryukov and Romanenko, 2017b; Akhmetshin and Gayazova, 2017). Conceptual features of advanced approaches to the study of entrepreneurship are determined by the principle of methodological individualism that underlies the basic economic theory. In these conditions, the search for a meaningful answer to the causes and 
motivational-behavioral mechanisms of entrepreneurial activity inevitably reveals the inadequacy of standard tools, actively used concepts, and economic models, which are usually based on the theory of rational choice of individualistic methodology (Kurniady, Komariah, and Karnati, 2019).

Within the framework of heterodox leadership based on the methodology of holism, several structural theories arose in which culture was recognized as a key structural phenomenon, and its relationship with economic behavior seemed to be endogenous (Tahir, Hattab, and Mappatoba, 2020). At the same time, hyper-deterministic interpretations of the role of cultural factors developed, which presented cultural values that shaped economic behavior as being outside the boundaries of the subjects' initiative and decisions (Williamson, 1965).

The limitations of established approaches based on the absolutization of the individualism and holism methodologies required the development of a broader economic and cultural paradigm supported by the ideas arising from the cognitive and cultural turn in the social sciences and associated with the formation of a methodological paradigm. In economics, the methodological "turn to culture" implies a break with positivism, which dominated in the cognitive domain for most of the 20th century. This turnaround of the last decade has allowed the humanities and social sciences to rethink the tools of methodological research and conceptual apparatus, and also contributed to the emergence of new cognitive domains.

Fukuyama (2004) sees a way out of the current situation of economic science in the following: a modern economic theory should withdraw as far as possible from the narrowness of the neoclassical version and return to the classical scope, considering how culture affects human behavior in general and economic behavior in particular. Today, as Lal (2007) notes, many theoretical economists find the issue of culture and economic development vague, confusing, and stupid, although professionals involved in elaborating economic development programs emphasize the significance of culture.

Current social practice has mainstreamed a new class of complicated socio-economic problems, the scale of which exceeds the gnoseological capabilities of special sciences. And, in this regard, it becomes increasingly important to study society as a self-developing and complex whole, established by the category "culture". The term "culture" is still not defined in economic studies; in many publications, culture is considered as a phenomenon expressed in values, preferences, or beliefs (Guiso et al., 2006). Over the past decade, the sociological, and philosophical, and cultural literature provides the widespread understanding of culture as a socio-code, a complex and historically developing system of supra-biological programs, 
manifested in symbolic forms, which help preserve, disseminate and generate knowledge and ideas about the world used for solving practical problems and adapting to the material and social environment (Biryukov and Romanenko, 2017c). Values form the core of culture; mutual understanding and interaction of business entities arise on their basis. Individual beliefs acquired through cultural transmission are gradually updated as experience is being gained, from generation to generation (Guiso et al., 2008).

Competing theories based on methodological individualism and holism fail to explain the behavior of the economic agent, the national economy, and world markets. A satisfactory solution to any economic and institutional problem requires going beyond these methodologies and finding new boundaries. The proper inclusion of the cultural and axiological context in the economic system can become such a new boundary in understanding economic reality, enabling to regard changes in economics and entrepreneurial behavior as a manifestation of the cultural process and the development of the value system as the core of culture (Saubanov and Nikolaev, 2018). According to Klamer (2003), today there is an alternative to the positivist vision of the economy, focused exclusively on the theory of rational choice, and this alternative, in contrast to the path of choice, plays the role of the path of values.

\section{Methodology}

An interdisciplinary methodology that combines the provisions of the theory of synergetics and complex systems, socio-cultural systems and multicultural modernization, social constructivism and communications, metaethics and the systemic-proactive concept; methods of theoretical and empirical research (abstract-logical, and comparative-analytical methods, interpretation, typologization, observation, grouping and generalization) form the methodological background of the research. The study is based on the developed methodological approach that provides a synthesis of the methodology of individualism and holism and expands its problem field in accordance with the intersubjective nature of economic reality (Hodgson, 2008; Biryukov, 2016). Within the framework of this methodological approach, a new economic and cultural paradigm for the study of entrepreneurship was proposed.

\section{Results}

The research is relevant because of the formed qualitatively new wave of global changes in the national economy that is caused by an alteration of the nature and mechanisms for 
entrepreneurial activities, the growing role of culture and its systemic impact on the formation of the key parameters of economic processes.

A new economic and cultural paradigm for the study of entrepreneurship was proposed. Significant progress has been made in understanding the phenomenon of entrepreneurship, studying the functions of the entrepreneur, characteristics and features of his behavior. First, the entrepreneur performs a valuable cognitive function. This function is related to the study of the business environment and the identification of technological and market trends for to get a systemic effect. Secondly, entrepreneurs' functions involve the introduction of technical and economic innovations based on the search for new opportunities and the formation of new combinations of economic resources. Thirdly, the introduction of organizational and economic innovations makes it possible to eliminate barriers and restrictions established by the level of knowledge and existing forms of business organization. Fourth, entrepreneurs implement cultural and axiological changes in the organization of relations in the internal and external environment. Fifth, entrepreneurship serves as a special mechanism and vehicle for structural changes in an innovative economy, which act as a factor of economic growth. Sixth, entrepreneurs' functions include the formation of the transformational path of the national economy, a change in the models of its development, and a change in the type of modernization.

The study showed that various agency theories are formed within the framework of the economic "mainstream" based on the methodology of individualism. They cannot solve the problem of endogenizing cultural variables because of their paradigmatic vision of the specifics of structuring the space in which economic processes take place. These variables act as exogenous factors in the environment of individual actions, although they are used as noneconomic variables to explain the influence of the cultural context.

Conclusions substantiated that agency theories inevitably interpret the role of culture to a very limited extent - most often as one of the factors that represent an obstacle (barrier) and affect the value of transaction costs in the implementation of innovative changes. At the same time, the peculiarities of cultural and value-based orientations are not taken into account and the fact that they can change and act as a powerful organizational resource is overlooked. Within the framework of economic and cultural paradigm, the provision concerning the endogenous nature of the ties of culture with economic behavior and entrepreneurial activity is substantiated (Figure 1). 


\begin{tabular}{|c|c|c|c|c|}
\hline \multicolumn{2}{|c|}{ C U L T URE } & $\begin{array}{c}\text { Culture as part } \\
\text { of economic activity }\end{array}$ & \multicolumn{2}{|c|}{$\begin{array}{l}\text { Economic forms } \\
\text { of cultural expression }\end{array}$} \\
\hline $\begin{array}{c}\mathrm{M} \\
\mathrm{E} \\
\mathrm{T} \\
\mathrm{A} \\
- \\
\mathrm{C} \\
\mathrm{U} \\
\mathrm{L} \\
\mathrm{T} \\
\mathrm{U} \\
\mathrm{R} \\
\mathrm{E}\end{array}$ & $\begin{array}{l}\mathrm{N} \\
\mathrm{A} \\
\mathrm{T} \\
\mathrm{I} \\
\mathrm{O} \\
\mathrm{N} \\
\mathrm{A} \\
\mathrm{L} \\
\end{array}$ & $\begin{array}{c}\text { National } \\
\text { features of } \\
\text { entrepreneurial } \\
\text { culture }\end{array}$ & $\begin{array}{l}\text { National features } \\
\text { of forms economic } \\
\text { activity } \\
\begin{array}{c}\text { National } \\
\text { peculiarities of } \\
\text { norms, rules } \\
\text { and forms of } \\
\text { business } \\
\text { activity }\end{array}\end{array}$ & $\begin{array}{c}\text { M } \\
\mathrm{E} \\
\mathrm{T} \\
\mathrm{A} \\
- \\
\mathrm{E} \\
\mathrm{C} \\
\mathrm{O} \\
\mathrm{N} \\
\mathrm{O} \\
\mathrm{M} \\
\mathrm{Y}\end{array}$ \\
\hline
\end{tabular}

Figure 1. The relationship between culture, economy and entrepreneurship.

This allowed for determining the role of cultural and value tools in making entrepreneurial choices and to identify the basis for building a holistic vision of the process of forming motivational and behavioral mechanisms of entrepreneurship. The importance of the influence of culture on the economic development of countries and companies, and cultural factors and variables - on the implementation of certain business activities and making various business decisions is proved. This made it possible to expand the subject area and meaningfully interpret entrepreneurial activities as a special form of implementing the cultural process, to deepen the existing ideas about the mechanism of the influence exerted by culture on the logic of decision-making and entrepreneurs' behavior.

\section{Discussion}

Guided by the complementarity of the structural-functional and communicativesemantic approaches, we proposed an alternative to competing approaches based on the methodology of individualism and holism. This methodology is based on ideas that arise under the influence of the cognitive-cultural turn in the social sciences. The essential significance of the proposed economic and cultural paradigm lies in clarifying the role of culture as a backbone factor of business activities (Alesina \& Giuliano, 2015; Boyer \& Petersen, 2012; Caroll, 1996; Schultz, 2001; Schwartz \& Weber, 2006). 
The proper inclusion of culture in economic processes is associated with a paradigmatic revision of the traditional view that culture as a separate sphere of society's life has external exogenous connections with other spheres, including economics. As a result, their mutual influence occurs. In contrast to the dominant theories of entrepreneurship and economic development, which are based on the methodological principles that absolutize the autonomy of culture and interpret its impact on the business as the influence of purely non-economic factors, economic culture should be regarded as a supporting structure of a single economic reality (Berger, 1994; Klamer, 2003; North, 1997; Staveren, 2009; Fukuyama, 2004). We should consider entrepreneurial culture as a special segment of economic reality and its culture as a structure that forms systems of models of entrepreneurial behavior and complex entrepreneurial practices.

As opposed to static, universalist, relativistic, linear-deterministic, and other simplified concepts, culture today is perceived as a complex, multi-level and dynamic system that manifests itself in various forms (national, economic, entrepreneurial, etc.). It provides the reproduction and alteration of reality based on cultural creativity embodied in mental structures containing elements of tradition and innovation. The economic culture of each country characterizes the originality of the national culture, national peculiarities of the world cognition and a model of thinking that combines values, cognitive and expressive (affective) elements and absorbs accumulated experience and knowledge, all the variety of ideas, and various topics about business processes (Ang \& Massingham, 2007; Biryukov, 2018; Romanenko \& Rakhuba, 2018). In the context of economic culture, three main mechanisms of its impact on the behavior and communicative practices of corporate entities can be distinguished: subjective, localcollective, and macro-collective, which are based on specific ways of semantic perception of the value of economic reality and the decision-making process. The core of corporate culture is a system of economic values. It is a particular economic culture of the country, and it plays a crucial role in the formation and transformation of positive and negative elements of the general appearance of economic culture, which in turn are significantly influenced by the latter (Romanenko \& Rakhuba, 2018).

Acting as a form of manifestation of collective consciousness, the entrepreneurial culture combines general and individual elements that characterize the peculiarities of the entrepreneur's perception of systemic connections and trends in the economic reality. It underlies the formation of expectations of possible target orientations and behavioral characteristics of various actors. Since it is a complex and multidimensional phenomenon, the 
culture of entrepreneurial activity characterizes the totality of mental and creative skills and abilities associated with its implementation, a combination of knowledge, beliefs, values, and ideological views acquired in the process of socialization. The culture of entrepreneurial activity is a kind of a set of symbolic tools used by entrepreneurs in everyday life to increase the production of added value based on the construction of innovative business ideas and business programs concerning socio-cultural conditions and other structures.

Entrepreneurial activities are best manifested in characterizing an entrepreneur as a subject. An entrepreneur can take risks and effectively combine factors of production on a proactive and innovative basis, and with economic responsibility, aiming to obtain additional income in the future through synergistic effects. The proposed economic and cultural paradigm contributes to the formation of a systemic and holistic vision of entrepreneurship.

There are two approaches to the analysis of the content of business activity in current conditions (Afanasieva, 2010). The first approach is that of linear equilibrium; it is based on a closed chain "entrepreneur - company - environment for its development" and focuses attention on the entrepreneurs and their activities in specific conditions of the business environment. In this case, the entrepreneur is perceived as an objective factor that does not change over time. This approach is justified in the terms of local "problems of survival". However, in passing to "development goals", when the question arises why entrepreneurship is developing dynamically in some countries and fails in others, the self-sufficiency of the approach disappears.

The second approach is an interactive, non-linear, non-equilibrium, or synergistic one. It draws attention to the interdependencies between the entrepreneur, the firm, and the business environment. According to this approach, entrepreneurship is defined as the process of selfrenewal and self-organization of people and business, carried out in interaction with the microand macro-environment of their functioning. The goal is to maximize the entrepreneur's ability to meet a complex of socio-economic needs within the uneven dynamic balance of conflicting interests of the participants (individuals, business entities, and society as a whole). "An entrepreneur is defined here as "a self-organized person with intuition, creative energy, ability to be an innovator, patriot, and philanthropist, committed to the principles of social responsibility" (Akhtyamov and Likholetov, 2008, p. 137). Most interpretations of the concept of "entrepreneur" relate rather to people of a certain type than to professions. Hizrich and Brush (1985) notes that entrepreneurs can be found in all areas - education, medicine, science, law, architecture, manufacturing, social sphere, and distribution. "Entrepreneurship is the process of 
creating something new having some value; it is a time-and-effort-consuming process, involving the assumption of financial, moral, and social responsibility; a process that results in monetary income and personal satisfaction with what has been achieved" (p. 18).

In the modern economy, entrepreneurship is becoming the most important factor in determining the success of the entire innovation cycle. The entrepreneurial function is implemented at all stages of the innovation process, including functional and applied research, development, implementation in production, and product replication. Nevertheless, it is important to distinguish between the roles that the research engineer and the entrepreneur play in the life cycle of creating and using innovations. According to Schumpeter (1982, p. 185), "new discoveries and inventions are constantly replenishing the existing stock of knowledge... The function of the inventor and general technician does not coincide with the function of the entrepreneur. As such, an entrepreneur is not a spiritual creator of new combinations of resources".

Culture is the most important element of entrepreneurial activities and a prerequisite for the normal functioning of an innovative economy. Increased activity is one of the most important factors in economic growth. Entrepreneurship performs various functions, including general economic ones, the introduction of technical and economic innovations, the introduction of organizational and economic innovations, the provision of cultural and valuebased changes in the organization, the spread of local economic innovations, and the transformation of models of national economic development (Biryukov, and Biryukova, 2010). The role of entrepreneurship is implemented through these functions.

As Teece (2009) notes, the business management function is a new hybrid of business management capitalism and includes identifying problems and trends, targeting resources, changing organizational structures and systems to create and use technological capabilities to meet consumers' needs. To be successful, companies must create and use three classes of skills (skills to recognize, explore, and change opportunities). If an entrepreneur is good at all three abilities, the organization has much better chances of success.

The formation of a particular mode of production depends on the technologies used in society; in turn, they are directly related to the knowledge accumulated and created in this society. However, knowledge by itself does not yet lead to the emergence of new, more advanced industries. The introduction of new technologies and the creation of a new product, the emergence of a certain technical and economic structure largely depends on the entrepreneurial talent of people who contribute to the creation of new technologies based on 
certain knowledge and disseminate new technologies throughout the society and the culture of entrepreneurial activities.

\section{Conclusion}

As a result of the research, an approach has been developed that provides a systemic and holistic vision of entrepreneurship development, with special attention paid to cultural and economic factors. The conceptual meaning of the developed economic and cultural paradigm for the study of entrepreneurship lies in clarifying the role of culture as a backbone factor in the development of entrepreneurial activities, which can be presented as a special form of the implementation of the cultural process, enabling to deepen the existing understanding of the mechanism for the culture to influence the logic of decision making and the entrepreneurs' behavior.

The main provisions and conclusions presented in the article contribute to the expansion of the problematic field and the deepening of theoretical ideas about culture as a special sphere of society's life, which has external links with the economy. These provisions and conclusions can be used for the further development of theoretical and empirical research on this issue and in practice when developing strategies and tactics that need to be implemented to improve the effectiveness of economic policy and entrepreneurial activities.

\section{References}

Afanasieva, M.V. (2010). Comparative analysis of the main approaches to the concept of business activity. Proceedings of the Tula State University. Economic and Legal Sciences, 1-2, 221-230. http://cyberleninka.ru/article/n/sravnitelnyy-analiz-osnovnyhpodhodov-k-ponyatiyu-delovaya-aktivnos... (socionet.ru)

Akhmetshin, R., Gayazova, E. (2017). About the features of perception of social entrepreneurship in the world. Journal of History Culture and Art Research, 6(4), 655664. doi:10.7596/taksad.v6i4.1159.

Akhtyamov, M.K., and Likholetov, V.V. (2008). Integration of "waves" in the theory of enterprise and concepts of G.S. Altshuller and I.M. Vertkin's theory of creative personality development. Russian Business, 4(2), 136-139. https://cyberleninka.ru/article/n

Alesina, A. (2016). Review of political order and inequality: their foundations and their consequences by Carles Boix. Journal of Economic Literature, 54(3), 935-941. https://www.aeaweb.org/articles?id=10.1257/jel.20151366 
Alesina, A. and Giuliano, P. (2015). Culture and institutions. Journal of Economics Literature, 53(4), 898-944. https://www.researchgate.net/publication/287387695

Alesina, A. and Giuliano, P. (2016). Culture and institutions. Part I. Voprosy Ekonomiki, 10, 82-111. https://doi.org/10.32609/0042-8736-2016-10-82-111

Algan, Y. and Cahuc, P. (2004). Trust, growth, and well-being: New evidence and policy implications. In Aghion, Ph., Durlauf, S.N. (Eds.). Handbook of Economic Growth, V. 2A. Amsterdam and San Diego, pp. 49-120. North-Holland: Elsevier. https://doi.org/10.1016/B978-0-444-53538-2.00002-2

Ang, Z., Massingham, P. (2007). National culture and the standardization versus adaptation of knowledge management. Journal of Knowledge Management, 11(2), 5-21. https://www.researchgate.net/publication/220363337

Atkin, D. (2016). The caloric costs of culture: evidence from Indian migrants. American Economic Review, 106(4), 1144-1181. https://docviewer.yandex.ru/view/213284733/

Barsbai, T., Rapoport, H., Steinmayr, A., Trebesch, C. (2017). The effect of labor migration on the diffusion of democracy: evidence from a former Soviet Republic. American Economic Journal: Applied Economics, 9(3), 36-69. https://papers.ssrn.com/sol3/papers.cfm?abstract_id=2327441

Berger, P. (1994). Capitalist Revolution: 50 theses on the prosperity, equality and freedom. Moscow: Progress-Universal. http://www.ejnew.org/?a=note\&id=34627

Biryukov, V.V. (2017c). Economic behavior of business entities, culture, and institutions: Specifics of their interrelations in conditions of neo-industrialization. European Research Studies Journal, 20(4), 370-385. https://www.ersj.eu/dmdocuments/2017-xx4-a-26.pdf

Biryukov, V.V. (2016). Valuable and rational behaviour and system and evolutionary paradigm of structuration of economy. The Russian Automobile and Highway Industry Journal, 3(49), 119-132. https://doi.org/10.26518/2071-7296-2016-3(49)-119-132

Biryukov, V.V., Biryukova, V.V. (2010). Development of entrepreneurship and economic changes in the Russian industry: monograph. Omsk: SibADI. bek.sibadi.org/fulltext/EPD43.pdf

Biryukov, V.V., Romanenko, E.V. (2017a). Culture and institutional structuring of the economy. $\quad$ Espacios, $38(51), \quad 6$. https://www.revistaespacios.com/a17v38n51/17385106.html

Biryukov, V.V., Romanenko, E.V. (2017b). Culture and institutions in the evolutionary economy: conceptual approaches to analysis. Vestnik SibADI, 2(54), 151-158. https://doi.org/10.26518/2071-7296-2017-2(54)-151-158

Biryukov, V. (2018). Culturological paradigm of the perception of economic reality. Obshchestvo i ekonomika, 9, 91-101. doi:10.31857/S020736760001440-3 
Boyer, P. and Petersen, M. (2012). The naturalness of (many) social institutions: Evolved cognition as their foundation. Journal of Institutional Economics, 8(1), 1-25. doi: $10.1017 /$ S1744137411000300

Caroll, A.B. (1996). Business \& society. Ethics and stakeholder management. Cincinnati: South Western College Publishing.

Couto, J.P., and Vieira, J.C. (2004). National culture and research and development activities. Multinational Business Review, 12(1), 19-35. https://pdfs.semanticscholar.org /4f17/2fb1a2919fcff54b2a0a19267121887ca5a9.pdf

Fernandez, R. (2008). Culture and economics. In Durlauf, S.N., Blume, L.E. (Eds.). The New Palgrave Dictionary of Economics, 2nd ed., pp. 330-340. N.Y.: Palgrave Macmillan. https://philpapers.org/rec/DURTNP-2

Fernandez, R. (2010). Does culture matter? In Benhabib, J., Jackson, M.O., Bisin, A. (Eds.). Handbook of Social Economics, V.1A, pp. 481-510. Amsterdam and San Diego: Elsevier. DOI 10.3386/w16277(http://www.nber.org/papers/w16277)

Frolov, D. (2016). Methodological institutionalism 2.0: from institutions to institutional configurations. Voprosy Ekonomiki, 7, 147-160. https://doi.org/10.32609/0042-87362016-7-147-160

Fukuyama, F. (2004). Trust: the social virtues and the creation of prosperity. Moscow: AST, Ermak.

Geertz, C. (2004). The Interpretation of Cultures. Moscow: ROSSPEN.

Guiso, L., Sapienza, P., Zingales, I. (2006). Does culture affect economic outcomes? Journal $\begin{array}{lll}\text { of Economic } & \text { Perspectives, }\end{array}$ https://www.researchgate.net/publication/4981762

Guiso, L., Sapienza, P., Zingales, I. (2008). Social capital as good culture. Journal of European $\begin{array}{lll}\text { Economic } \quad \text { Association, } & \text { 6(2-3), }\end{array}$ https://www.nber.org/system/files/working_papers/w13712/w13712.pdf

Guiso, L., Sapienza, P., Zingales, I. (2009). Cultural biases in economic exchange. Quarterly $\begin{array}{llll}\text { Journal of } & \text { Economics, }\end{array}$ www.socialcapitalgateway.org/content/paper/

Hisrich, R. D., Brush, C. G. (1985). The Woman Entrepreneur: Starting, Financing and Managing a Successful New Business. Lexington, Mass., Lexington Books.

Hodgson, G. (2008). Institutions and Individuals: Interaction and Evolution. Voprosy Ekonomiki, 8, 45-60. https://doi.org/10.32609/0042-8736-2008-8-45-60

Kayworth, T., Leinder, D. (2004). Organizational culture as a knowledge resource. In Holsapple C.W. (Eds.). Handbook on Knowledge Management 1: Knowledge Matters, pp. 235-252. Berlin: Springes-Verlag. https://link.springer.com/chapter/10.1007/978-3- 


\section{$\underline{540-24746-3 \quad 12}$}

King, W.R. (2007). A research agenda for the relationships between culture and knowledge Management. Knowledge \& Process Management, 14(3), 226-236. https://www.researchgate.net/publication/229708027

Klamer, A.A. (2003). Pragmatic View on values in Economics. Journal of Economic Methodology, 10(2), 192-212. https://ru.scribd.com/doc/270069371

Kurniady, D.A., Komariah, A., Karnati, N. (2019). A heutagogy approach in pensioner entrepreneurship training. Journal of Southwest Jiaotong University, 54(3). https://doi.org/10.35741/issn.0258-2724.54.3.30

Lal, D. (2007). Unintended consequences. The effect of endowments of the factors of production, culture, and politics on long-term economic results. Moscow: IRISIN. https://www.litres.ru/dipak-lal

North, D. (1997). Institutions, institutional dimensions and economic performance. The Fund of economic book «Nachala», Moscow.

O'Hara, P. (2009). Contemporary principles of heterodox political economy. Issues of Economics, 12, 38-57. https://doi.org/10.32609/0042-8736-2009-12-38-57

Romanenko, E.V., Rakhuba, L.F. (2018). Theory and Methodology of Small Business Development in an Innovative Economy. International Scientific Conference "Far East Con" (ISCFEC 2018). Proceedings of the International Scientific Conference, Vladivostok, Russian Federation, 2-4 October, 2018. Paris: Atlantis Press. https://doi.org/10.2991/iscfec-18.2019.186

Saubanov, K., \& Nikolaev, M. (2018). Evolution of the content of the market category at different stages of its development. Journal of History Culture and Art Research, 7(4), 192-198. doi:10.7596/taksad.v7i4.1835.

Schumpeter, J. (1982). The theory of economic development. Moscow: Progress. https://institutiones.com/download/books/713

Schultz, W. (2001). The Moral Conditions of Economic Efficiency. Cambridge: Cambridge University Press.

Schwartz, M.S. and Weber, J. (2006). A business ethics national index (BENI): Measuring business ethics activity around the world. Business and Society, 45(3), 382-405. doi: $10.1177 / 0007650305285395$

Staveren, I. (2009). Ethics of efficiency. Voprosy Ekonomiki, 12, 58-71. https://doi.org/10.32609/0042-8736-2009-12-58-71

Tahir, D., Hattab, S., Mappatoba, M. (2020). Building public trust through service quality based on leadership and organizational culture. Journal of Southwest Jiaotong University, 55(3). http://jsju.org/index.php/journal/article/view/602

Williamson, J.G. (1965). Regional Inequality and the Process of National Development: a 
Description of the Patterns. Economic and Cultural Change, 13, 1-84. https://www.journals.uchicago.edu/doi/pdf/10.1086/450136 